\title{
Innovation analysis of the ideological and political education reform in Colleges and Universities under the new media environment
}

\author{
HE LIN ZHI \\ Vocational and technical college of zhengzhou city, henan province, zhengzhou, henan province, \\ zhengzhou 450121
}

Keywords: new media, ideological and political education; Colleges and Universities

\begin{abstract}
: in the new media environment, universities' ideological and political education mode and means all need timely updates. In this paper, the characteristics and disadvantages of ideological and political education in Colleges and Universities under the new media era are analyzed in detail, the impact and change of the new media on ideological and political education of universities are analyzed. Taking the ideological characteristics of contemporary college students as the basis, combined with the current development characteristics and the way of information dissemination, develop educational programs targeted, to make educational activities to achieve the desired effect.
\end{abstract}

\section{Influence of new media form on College Students' values}

With the rapid development of mobile media, so that the number of China's mobile phone users quickly upgrade[1-3]. When college students were admitted, everyone has a mobile phone, and 90\% for smart phones, which provides a more convenient platform for college students through mobile media to understand a variety of information[4-6].

According to the survey, college students have a high degree of dependence on the phone, most people talk about the Wechat, Weibo in the free time, become a veritable mobile control. Most of the students use cell phones 2-3 hours in every day, some even more than 5 hours, only few people in 1 hours, which showed a more dependent on mobile media of College students.

\section{The characteristics of the ideological and political work in the new media era}

The characteristics of the new media environment make the ideological and political education to undergone unprecedented changes. New media opens up a new field for ideological and political education. Network media is a new media technology and information communication tools, through the tool, people can exchange ideas, disseminate information, express emotion, to make the ideological and political education entered to a new and very broad field. In this field, the contents of ideological and political education become very rich, the scopes become very broad, the forms become more and more diverse, the patterns become more invisible, the situations become more complex, and the difficulties become bigger. Therefore, the ideological and political education field under new network media environment, is a different, multidimensional, and new field which is full of temptation and is not easy to control.

\section{New media creates a new platform for ideological and political education}

With the huge amount of information, high speed transmission, strong interaction and multiple modes, network and short message have become the cultural thought dissemination carrier, the carrier has offered the new platform for ideological and political education. Ideological and political educators can effectively make use of this platform,to make the main melody ideological publicity of Marx nationalism, socialism, patriotism, and collectivism, dissemination of advanced thoughts and culture and the scientific and democratic spirit, and the education of world outlook, outlook on life, values and moral outlook. New mediaprovides a new model of fast, open, democratic, interactive, and largely promotes the update and conversion of Ideological and political education mode. The traditional education mode and method already could not adapt to the demands of 
ideological and political education in network information age. the mode with centralized and "one size fits all”, superincumbent and unidirectional inculcating, simple command didactic is gradually alternated by new mode with rich diversification, bidirectional (TRAP) and direct communication (interaction), using multimedia and illustrated, audio and video. A new ideological and political education mode is established. New media puts forward higher requirements for ideological and political education, how to effectively use of new media, new network technologies to enrich the new content, convert new mode, expand the influence, enhance convincing, strengthen pertinence, and improve the effectiveness, is the fundamental faced problem of ideological and political education under the new media environment.

\section{The important role of the mobile media in ideological and political education of College Students}

The effectiveness of mobile media in ideological and political education of college students. In the past, the use of traditional means of education is mostly limited by space and time, the information transmission distance is too long between the ideological and political educator and the education receiver, and it cannot be timely communication.

At the same time, the education information is lagging behind, educator cannot timely transmit the information to the education object. While through the mobile media, educators can use a variety of mobile phone platforms such as WeChat, QQ and other communication tools, to contact with students very conveniently, and carry out ideological and political education whenever and wherever possible. The hot issue and hot events occur in current social are transmitted by the mobile media platform to make the information to the students, and provide timely comment on these information, making public opinion guide work, and forming a positive, correct public opinion atmosphere, so as to make full use of effectiveness of mobile media.

The guiding role of mobile media in ideological and political education of college students. Compared with the traditional media, mobile media combines broadcast, television, network, newspapers, magazines and other forms of media, so that the mobile media contains more rich content, which offers a number of educational material, rich educational resources for college students' Ideological and political education. At this time, mobile media serves as the guidance for politics and morality. In the global information technology background, students can be aware of the various social world's major events and news via mobile media, various political consciousness filled with students' thinking, which makes the ideological and political education for college students more difficult. Educators should be through the mobile media to transmit correct political ideas, provide the correct research results of ideological education, for students learning and reading, and timely correct the appeared ideological and political problems of college students, making university students to establish the correct political ideas. At the same time, educators can be through mobile media to positive public the social events which promotes moral values. Through the learning and deepen of these positive moral concept, make university students to establish the correct moral values.

The innovation function of mobile media for ideological and political education of college students. The traditional ideological and political education mostly used the classroom as the main teaching place, with the main teaching way of face to face, and the main method of bring the facts and truth, to produce a one-way information exchange and passive mode between students and educator. This traditional mode has produced good effects, but in today's information technology is not enough.

The use of mobile media can provide some new methods for ideological and political education of college students. Mobile media as a communication platform for educator and college students', can make the two-way transmission of information. The educators can transfer the content, policy, and events of ideological and political education through mobile media to college students in first time; college students can also feedback the content of education, the view of event point, and the existing problems timely to educators, making that the educators can immediately answer, which greatly improves the convenience of education. At the same time, mobile media can make sound, 
picture, text and so on as an integrated, so as to make the teaching more vivid, let the students to accept the ideological and political education in a happy mood.

The environmental influence effect of mobile media in ideological and political education of college students. In the era of information globalization background, mobile media has broken through the limitation of time and space, everywhere, always affects people all aspects of social life. People can receive from all sides of the information through the mobile media, students are no exception, their learning and life created in mobile media environment. This will enable college students influenced by mobile media environment, the influences are omnipresent, and get in by every opening. In the past, the educators cannot make the ideological and political education content to spread widely, mostly it used by the way of making report and sending materials, the dissemination way is single, and the transmission range is narrow. But, through the mobile media, educators can make the correct political ideology, moral concept, value concept to spread widely, and let the students grow in the correct ideological and moral atmosphere, improving students' ideological and political quality, to achieve the goal of comprehensive quality education.

\section{The main highlights problem of college students' Ideological and political education in mobile media age}

Along with the network technology is deepening, colleges ideological and political education faces severe development challenges in the current context of new media. College students have strong desire to seek knowledge, the ability to accept new things, but also they inevitably will contact some bad information. If it don't realize the seriousness of the problem, they will gradually deviate from the right direction of ideological and political education. In view of the emergence of new media network, we thought that the ideological and political education of university, is absolutely cannot continue to apply mechanically the tradition contents and methods under the new media environment, so as to promote the improvement of the level of students' ideological and political.

In the process of carrying out the ideological and political education of colleges and universities, if it is combined with the culture of the network, it will achieve good teaching effect. First of all, teachers can determine the subject, then ask students to use the network media to carry out a series of classroom teaching activities. In addition, in the face of the dual pressure of society and learning, many students are addicted to the Internet, online games, leading to the occurrence of various events. To make a long story short, the college students are the main force to promote the future development of society of our country, if they long-term addicted to the Internet, it will gradually lose the basic ability based on society. For Ideological and political education of university, it should be beginning start relevant educational activities in the student to enter the campus, in a responsible attitude to explain the malignant induction in the network to students, making them to produce psychological resistance to low moral behavior in the virtual environment, to cultivate students' healthy habits for network.

\section{Effective way of Mobile media to enhance the actual effect of ideological and political education of College Students}

To improve the comprehensive quality of education, strengthen the construction of teaching staff. The mobile media should be as one of the main means of ideological and political education.

First of all, let educators to master the propagation law of mobile media. As a college educator, who should not only have profound knowledge and academic level, but also fully understand the cultural characteristics of mobile media, master mobile media propagation.Secondly, to increase the number ofideological and political educator of colleges and universities, make the work of college students' ideological and political education to be carried out widely. Thirdly, to improve the education researchers' keen awareness of information. Educators should be familiar with each kind of network language used among college students, thus educators and students are easier to establish a close relationship, which is conducive to the exchange of ideas, to provide convenience 
for the work of ideological and political education.

To strengthen the guidance, improve the ability of college student's information identification and judgment. College students should improve their own ability of information identification and judgment, make scientific identification of these media information, discard the false and retain the true information, and timely reflect on these issues. College students should improve the ability of network self-discipline, understand what can do and cannot do on the web, and correct their bad tendencies timely, so as to achieve the purpose of improving college students' ideological and political state.

The use of mobile media, broaden the field of ideological and political education. With the come in of the mobile media era, it creates new opportunities for ideological and political education of university students, and proposes the new challenge. College educators should stay calmly, make full use of mobile media, and actively expand the field of ideological and political education. First of all, the university should establish their own public official website, Weibo, and WeChat ID for the ideological and political education, timely publish the information of ideological and political education, and enhance the richness and vividness of content, to attract students' attention. Secondly, the construction of College mobile media should be combined with their respective characteristics of teachers and students. For example, to organize interactive quiz, prize quiz and other activities, let the students' participation actively, do their own characteristics. Thirdly, to strengthen the initiative of ideological and political education. Educators have to activity respond to the occurrence of hot events and hot issues, and carries on the evaluation in a timely manner, to give the students a correct guidance of public opinion information. Fourthly, society, college and family should work together to protect the network security. The safety of network culture always affects the effectiveness of the mobile media on college students' ideological education. The society should increase the investment in human and material resources, to create a good environment for network security. In this way, it can make the mobile media really used for ideological and political education of college students.

\section{Conclusion}

In a word, how to use the advantages of mobile media, to make the ideological and political education of college students to sit on this "fast train", and make that the traditional ideological education can be considerable development, is an important issue need to face by every college educators. in this article, it is mainly from the impacts of mobile media on students, the prominent role of education, and several aspects of faced problem of college students' ideological and political education, to try to find out an effective way to enhance the actual effect of ideological and political education in mobile media era, providing some new countermeasures for college students' ideological and political education work.

\section{References}

[1] E. Crawley. Rethinking Engineering Education, 2007

[2] Wooden,Sharon and others. ORIDING: An Adult Teaching-Learning Technique. Adult Learning, 1994

[3] N.C. Burbules. Dialogue in Teaching, 1993

[4] Legge,D. The Education of Adults in Britain, 1982

[5]National Advisory Council on Adult Education. Terms, Definitions, Organizations and Councils Associated with Adult Learning, 1980

[6] Jarvis. An International Dictionary of Adult and Continuing Education, 1990 